\title{
RODZINA A TERAPIA DZIECI NIEPEŁNOLETNICH W OŚRODKU REHABILITACJI DLA OSÓB UZALEŻNIONYCH OD SUBSTANCJI PSYCHOAKTYWNYCH W PAŁĘGACH
}

\section{FAMILY AND THERAPY OF UNDERAGE CHILDREN IN THE REHABILITATION CENTER FOR PERSONS ADDICTED TO PSYCHOACTIVE SUBSTANCES IN PALEGNA}

\author{
Justyna Pawelec ${ }^{1(A, B, C, D, E, F, G)}$
}

${ }^{1}$ Uniwersytet Jana Kochanowskiego w Kielcach

\begin{abstract}
Pawelec J. (2019). Rodzina a terapia dzieci niepełnoletnich w Ośrodku Rehabilitacji dla Osób Uzależnionych od Substancji Psychoaktywnych w Pałęgach. Rozprawy Społeczne, 13(1), 49-56. https://doi.org/10.29316/rs.2019.06

Wkład autorów:

A. Zaplanowanie badań

B. Zebranie danych

C. Dane - analiza i statystyki

D. Interpretacja danych

E. Przygotowanie artykułu

F. Wyszukiwanie i analiza

literatury

G. Zebranie funduszy

Streszczenie

Artykuł podejmuje tematykę oddziaływania rodziny na niepełnoletnich pacjentów podejmujących terapie w stacjonarnym ośrodku leczenia uzależnień w Pałegach. To zwłaszcza ona stanowi dla nich najważniejsze wsparcie poprzez motywowanie do leczenia i wzmacniania do zmiany. Autor przedstawia jakie działania ze strony opiekunów sprzyjają terapii, a jakie je zakłócają. Ukazuje jak wygląda procedura przyjęcia na terapię i realizacja kontraktu terapeutycznego przez opiekunów prawnych. Autor podjął rozważania na temat granic w relacjach z dziećmi oraz zachowań konsekwentnych, które w terapii uzależnień mają szczególne znaczenie. Stwierdza również, iż współpracując z rodziną można zrealizować określone cele terapeutyczne i skutecznie pomóc dziecku.
\end{abstract}

Tabele: 0

Ryciny: 0

Literatura: 16

Otrzymano: grudzień 2017

Zaakceptowano: czerwiec 2018
Słowa kluczowe: rodzina, nastolatek, terapia, uzależnienie

\section{Summary}

This article deals with the impact of a family on juvenile patients undergoing therapy in a stationary addiction treatment centre in Pałeggach. Family constitutes the most important form of support for patients through motivating them to undergo treatment and giving them the strength to change. The author outlines which actions of the caregiver are conducive to the therapy and which can interfere with it. It describes the procedure of patient's admission into therapy and the therapeutic contract with legal guardians. The author researches the topics of limitations in the relationship with children as well as consistency in behaviour, which is especially crucial in the addiction therapy. The author also concludes that, by cooperating with the family, the therapist can achieve the therapeutic goals and effectively help the child.

Keywords: family, teenager, therapy, addiction

\section{Wprowadzenie. Przybliżenie problematyki ba- dawczej oraz kontekstu teoretycznego}

W artykule podjęta została problematyka terapii uzależnień nastolatków $\mathrm{w}$ kontekście postaw członków rodziny wobec samej terapii. „W dzisiejszym szybko postępującym świecie, zjawisko uzależnienia jest częstym problemem społecznym. Uzależnienie może dotknąć każdą osobę, bez względu na płeć, wiek czy status ekonomiczny" (Palacz-Chrisidis 2014, s. 17), niestety problem ten wśród nastolatków nasila się. Celem artykułu jest poznanie szczególnych trudności związanych z postawami rodziny i jej członków wobec dzieci podejmujących terapię na przykła- dzie stacjonarnego Ośrodka Rehabilitacji dla Osób z Uzależnieniem od Substancji Psychoaktywnych w Pałęgach. Kolejnym celem jest przedstawienie możliwości współpracy z rodziną uzależnionego nastolatka, nakreślenie korzyści i barier podejmowanego kontaktu z rodziną. Artykuł powstał w znacznej mierze w oparciu o praktykę terapeutyczną autorki. Jest więc próbą poszerzenia wiedzy responsywnej, niezwykle przydatnej w refleksji pedagogicznej i terapeutycznej .

Wśród licznych teorii wyjaśniających powstawanie uzależnień od substancji psychoaktywnych na uwagę zasługują te, które wskazują na znaczącą (kierunkową) rolę uwarunkowań rodzinnych. Jedna z badaczek problemów uzależnień, J. Roga-

Adres korespondencyjny: Justyna Pawelec, Uniwersytet Jana Kochanowskiego w Kielcach, ul. Krakowska 11,25-029 Kielce, e-mail: jus22@o2.pl, tel. 601292 571. ORCID: http://orcid.org/0000-0002-2862-4304 Copyright by: Państwowa Szkoła Wyższa im. Papieża Jana Pawła II w Białej Podlaskiej, Justyna Pawelec 
la-Obłękowska (2002, s. 83), wskazuje na dwie płaszczyzny analiz podejmowanych przez badaczy narkomanii młodzieżowej - koncepcje psychoanalityczne i koncepcje systemowe. Koncepcje psychoanalityczne skoncentrowane są na ustalaniu rodzinnych czynników, mogących być przyczyną powstawania uzależnienia u dziecka. Zalicza się do nich m.in. teorię percepcji środowiska rodzinnego Freda Streita.

Wymienione wyżej teorie opierają się na założeniu wskazującym, że nieprawidłowo funkcjonująca rodzina jest istotnym prekursorem zachowań patologicznych wychowującej się w niej młodzieży. $\mathrm{Na}$ podstawie licznych badań autorzy tych teorii zauważyli, że wzorce rodzinne mogą skutkować szybszym sięganiem po substancje psychoaktywne, niższym wiekiem eksperymentów z narkotykami, jak również wyborem określonej substancji. Dorota Pstrąg uważa, iż nieprawidłowo funkcjonująca rodzina może spowodować ukształtowanie się osobowości dziecka podatnej na uzależnienie, jak również być powodem wielu stresogennych sytuacji, mogących stać się przyczyną inicjacji narkotykowej (Pstrąg, 2000, s. 32).

$\mathrm{Z}$ drugiej strony rodzina jest najważniejszym źródłem wsparcia dla niepełnoletnich pacjentów podejmujących terapię uzależnień. To właśnie ona stanowi źródło otuchy, nadziei, troski, zainteresowania oraz wzmacniania do osiągania określonych celów terapeutycznych. Rodzina, jak pisze Durka (2007, s. 139) „...jest najważniejszym środowiskiem w procesie wychowania i kształtowania swoich dzieci. To ona powinna stanowić źródło wsparcia i wzrostu. Prawidłowo funkcjonująca rodzina jest środowiskiem wychowawczym, ponieważ stwarza warunki do prawidłowego rozwoju uczuciowego, intelektualnego, a także przygotowuje do życia w społeczeństwie". Rodziny, w których rozwijają się osoby uzależnione są niezwykle zróżnicowane. Nie ma jednego typu, modelu rodziny, który determinuje powstanie i rozwój uzależnienia.

W literaturze przedmiotu znajdujemy potwierdzenie tych słów „w funkcjonowaniu rodziny można także znaleźć źródła zaburzeń emocjonalnych i zaburzeń zachowania, mogące sprzyjać uzależnieniu dzieci i młodzieży od środków chemicznych" (Rajwa, Marynowicz, 2002, s. 13). Okazuje się, że współpraca terapeutów z opiekunami dziecka może sprzyjać leczeniu jak i je zakłócać. Przede wszystkim warto wspomnieć o tym, że uzależnieni nastolatkowie pochodzą z rodzin ze zróżnicowanymi problemami.

Niektórzy rodzice wykazują małe zainteresowanie terapią dziecka i sporadycznie kontaktują się ze specjalistą terapii uzależnień co znacznie wpływa na osłabienie współdziałania rodziny z zespołem terapeutycznym.

Bez odpowiedniej współpracy z rodziną ograniczone są możliwości pomocy.

„Zrozumienie zagrożenia uzależnieniem jest niemożliwe bez zrozumienia prawidłowości rodziny i zaburzeń w jej funkcjonowaniu" (Rajwa, Marynowicz, 2002, s. 13). W związku z powyższym praca terapeutyczna z rodziną jest niezbędna, gdy pacjent zdecydował się na leczenie.

Warto zaznaczyć, że są rodziny otwarte na kontakt z zespołem terapeutycznym ośrodka, które stosują się do zaleceń terapeutycznych, gdyż wiedzą jakie to ma znaczenie dla terapii syna lub córki. Systematycznie kontaktują się ze specjalistą terapii uzależnień w celu pozyskania informacji o przebiegu terapii. Przyjeżdżają regularnie na spotkanie dla rodzin. Ponadto są otwarci na kontakt $\mathrm{z}$ terapeutą uzależnień w celu ustalenia właściwego kierunku współpracy, chętnie rozmawiają o swoich dylematach, rozterkach, pomysłach.

Czy można wyróżnić jakieś podstawowe, najczęściej występujące postawy rodziców i opiekunów wobec podejmującego terapię nastoletniego dziecka? Czy można wypracować na ich podstawie sensowne i skuteczne zalecenia dla rodzin dzieci uzależnionych? To podstawowe pytania, które pojawiły się u źródeł przedstawianej w niniejszym artykule refleksji.

\section{Metodologiczne założenia badań}

Przedmiotem prezentowanych badań jest sposób oddziaływania rodzicielskiego na niepełnoletnią osobę uzależnioną $\mathrm{w}$ momencie podejmowania terapii i w czasie jej trwania w perspektywie studium indywidualnych przypadków. Celem natomiast, staje się przedstawienie poszczególnych trudności, dotyczących postaw rodziny wobec terapii uzależnień ich niepełnoletnich dzieci.

Główny problem badawczy wyraża się w następującym pytaniu: „Jakie jest wsparcie rodziców (opiekunów) w terapii z uzależnienia niepełnoletniego dziecka?

Problem główny został uszczegółowiony w postaci następujących pytań:

- Czy rodzina motywuje uzależnionego niepełnoletniego wychowanka do terapii?

- Jakie problemy i trudności towarzyszą rodzinie uzależnionego dziecka w momencie przystąpienia do terapii oraz w czasie jej trwania?

- Jakie dominujące uczucia towarzyszą członkom rodziny (opiekunom) podczas leczenia z uzależnienia ich niepełnoletniego podopiecznego?

- Jakie zachowania i postawy rodziny niepełnoletniego pacjenta sprzyjają postępom w jego terapii?

- Jakie zachowania i postawy rodziny oddziałują negatywnie na terapię niepełnoletniego pacjenta?

W przeprowadzonych badaniach zastosowano metodę indywidualnych przypadków. Jest ona ściśle związana $\mathrm{z}$ praktyką terapeutyczną, bowiem zdecydowana większość terapeutów w swojej pracy właśnie na niej się opiera. Na ogół przez metodę indywidualnych przypadków rozumie się 
gromadzenie danych o rozwoju i życiu fizycznym, psychicznym i społecznym interesujących badacza osób. Dotyczy ona zwykle nie jakiejś grupy, społeczności czy instytucji, lecz pojedynczych ludzi. Jest nade wszystko - jak pisze T. Pilch - „sposobem badań polegającym na analizie jednostkowych losów ludzkich uwikłanych w określone sytuacje wychowawcze lub na analizie konkretnych zjawisk natury wychowawczej poprzez pryzmat jednostkowych biografii ludzkich z nastawieniem na opracowanie diagnozy przypadku lub zjawiska w celu podjęcia działań terapeutycznych", także wychowawczych (Pilch, Bauman, 2001, s. 298). Nierzadko jest nią wielostronna i dokładna analiza zachowań, postaw i osobowości człowieka, dokonywana zazwyczaj na przestrzeni dłuższego czasu i z uwzględnieniem środowiska, w jakim przypadło mu żyć (Łobocki, 2006, s. 3). W praktyce metoda ta daje możliwość obserwacji i aktywnego uczestnictwa $\mathrm{w}$ procesie pomocy $\mathrm{z}$ perspektywy nie tylko naukowca ale i terapeuty.

Praktycznie każde szersze opracowanie na temat metody indywidualnego przypadku zawiera określenie celów, dla których jest ono konstruowane. Większość przywoływanych wyżej autorów cele dzieli na trzy grupy:

- praktyczne - udzielenie adekwatnej pomocy,

- naukowe - poznanie i zrozumienie,

- dydaktyczne - nauczenie się czegoś nowego (Baranowicz, 2001, s. 116).

W niniejszym artykule analiza indywidualnych przypadków będzie kierować się celami zarówno badawczymi jak i praktycznymi. Aby je osiągnąć w pierwszej kolejności przedstawione zostaną założenia terapii prowadzonej w Ośrodku.

\section{Terapia w Ośrodku Rehabilitacji dla Osób Uza- leżnionych od Substancji Psychoaktywnych w Pałęgach}

Terapia niepełnoletnich osób uzależnionych charakteryzuje się określoną dynamiką. Jest to trudny proces, który wynika ze specyfiki uzależnienia. Dodatkowo brak gotowości do pracy terapeutycznej nad nałogiem cechuje zdecydowaną większość nastolatków przyjeżdżających do ośrodka. Często uwidacznia się tylko pozorna chęć czy zaangażowanie w leczenie, co w konsekwencji doprowadza do rezygnacji z terapii. U niektórych uzależnionych terapia przebiega $\mathrm{w}$ miarę stabilnie, a u innych może charakteryzować się zmiennością przejawiającą się brakiem zaangażowania i odpowiedzialności. Martien Kooyman uważa, że „uzależnieni postrzegani są jako osoby niedojrzałe i nieodpowiedzialne, które nie są w stanie odłożyć zaspokajania własnych potrzeb. W społeczności terapeutycznej mają okazję poznać własne możliwości oraz sposoby na osiągnięcie rozwoju emocjonalnego, fizycznego, duchowego, intelektualnego i seksualnego, a także nauczyć się wykorzystywania własnej twórczości" (Kooyman, 2002, s. 45). Właśnie społeczność tera- peutyczna jest metodą leczenia, na której oparte jest funkcjonowanie Ośrodka.

Ośrodek Rehabilitacyjny dla Osób z Uzależnieniem od Substancji Psychoaktywnych w Pałęgach prowadzi terapię $\mathrm{w}$ trybie stacjonarnym. Przyjmowane są osoby uzależnione od narkotyków, a także z uzależnieniami współwystępującymi tj. hazard, komputer, Internet, alkohol, leki. Leczenie jest bezpłatne i finansowane przez NFZ. Trwa od 7-12 miesięcy. Realizowany przez Ośrodek program kładzie nacisk na indywidualne podejście do pacjenta oraz profesjonalną diagnozę. Prowadzona jest terapia indywidualna i metodą społeczności terapeutycznej.

Warto wyjaśnić, iż „społeczność terapeutyczna (ST) to taka społeczność, która naprawia, przywraca, leczy. Ale podstawowa różnica między ST a innymi formami leczenia, innymi rodzajami społeczności polega na tym, że społeczność jest metoda zmiany całego człowieka" (De Leon, 2003, s. 116117).

Jolanta Koczurowska uważa iż „w społecznościach terapeutycznych istnieje szczegółowy podział zadań i obowiązków, które przydzielane są poszczególnym członkom w zależności od ich indywidualnej sytuacji. Oznacza to, że otrzymane zadanie lub funkcja pełni zawsze rolę terapeutyczną i jest poddawane ocenie pozostałych członków społeczności. Dopasowuje się też rodzaj pracy i zadań do możliwości fizycznych i psychicznych danej osoby oraz do jej statusu w społeczności (czy etapu, na jakim przebywa)" (Koczurowska, 2010, s. 190).

W ośrodku w Pałęgach podstawową formą aktywności członków społeczności jest praca związana z codziennymi czynnościami gospodarskimi, ogrodowymi czy domowymi. Ponadto pacjenci mają możliwość rozwijania swoich zainteresowań poprzez warsztaty kulinarne, stolarskie, ogrodnicze, plastyczne i muzyczne. W trakcie zajęć młodzież zyskuje wiedzę i nowe umiejętności. Ponadto zajęcia te stwarzają możliwość wzajemnego poznania się. Ośrodek współpracuje z rodziną poprzez spotkania terapeutyczne, które odbywają się raz w miesiącu. W trakcie terapii odbywają się zajęcia edukacyjne, które dostarczają wiedzy na temat uzależnienia. Atrakcją dla młodzieży są letnie i zimowe obozy terapeutyczne np. spływ kajakowy, wędrówki górskie, wycieczki.

\section{Uzależnienie determinantem trudności. Cha- rakterystyczne przypadki}

Wśród pacjentów zgłaszających się na leczenie bywają tacy, którzy po przyjeździe do ośrodka i przedstawieniu regulaminu oznajmiają, że nie będą podejmować leczenia. Wówczas wobec takiej decyzji dziecka, rodzice przeżywają trudne chwile,często przejawiają uczucia od złości do bezsilności. Głównym problemem, który się w takich sytuacjach uwidocznia jest brak gotowości i motywacji do pracy nad uzależnieniem. Niejednokrotnie zdarzają się sytuacje gdy niepełnoletni odmawia lecze- 
nia. Warto zaznaczyć, iż dziecko nie dostrzega strat i szkód w różnych sferach życia pomimo argumentów zdrowotnych, szkolnych, rodzinnych przemawiających za wskazaniem do terapii.

\section{Przypadek pierwszy: Kamil ${ }^{1}$, lat szesnaście - uza- leżniony od amfetaminy i dopalaczy.}

Wywiad diagnostyczny z rodzicami wskazywał na poważne zatrucie organizmu chłopca substancjami psychoaktywnymi, w wyniku czego często trafiał do szpitala na oddziały psychiatryczne. Nie podejmował leczenia, gdyż nie zgodził się na warunki jakie proponuje ośrodek. Kilka miesięcy po ostatniej próbie podjęcia leczenia w naszym Ośrodku spotkano się z uzależnionym na rocznicy innego ośrodka terapeutycznego. Okazało się, iż Kamil już trzeci miesiąc przebywa w ośrodku, zaangażował się w terapię. Był zadowolony, podejmował wiele zadań, które dawały mu radość. Z rozmowy wynikało, że decydującym motywem podjęcia leczenia był strach o swoje zdrowie i chęć odbudowania relacji z rodziną. Przytoczony przykład ukazuje, że niekiedy młodzi ludzie potrzebują czasu, żeby zrozumieć swój problem.

Rodzice czują bezsilność wobec uzależnienia i wobec tego za wszelką cenę chcą umieścić swoje dziecko w ośrodku. Z związku z tym zdarza się, że nie ujawniają ważnych informacji o chorobach dziecka z obawy, że nie zostanie ono przyjęte na leczenie. Gdy specjalista terapii uzależnień podejmie decyzję o przyjęciu danego pacjenta, to podlega on obserwacji, która ma na celu ustalenie czy pacjent nie stwarza zagrożenia dla siebie i innych. Zdarza się, że uwidaczniają się powikłania zdrowotne np. psychoza amfetaminowa i myśli samobójcze, które zagrażają życiu pacjenta. Samookaleczanie się występuje dość często wśród młodych pacjentów, zwłaszcza wśród dziewcząt zgłaszających się na terapię w Pałęgach. Takie zachowania są trudne do zaobserwowania, gdyż spotkałam się z przypadkiem, w którym szesnastoletnia Kinga wykazywała wstępną motywację do leczenia, a następnego dnia dokonała ran ciętych na przedramieniu. W takich sytuacjach terapeuci podejmują decyzję o skierowaniu pacjentów do szpitala psychiatrycznego.

Rodzice często odczuwają ulgę, gdy umieszczą dziecko w ośrodku uzależnień, tymczasem terapia dziecka dopiero się rozpoczyna. W trakcie leczenia pacjenci ujawniają problemy, trudności, napady złości, agresji, co może stanowić powód do rozwiązania kontraktu terapeutycznego. Opiekunowie nie zawsze są świadomi, jak ważna jest ich współpraca z terapeutami. Dla dobra dziecka ważna jest aktywność rodziców w przebiegu jego terapii. Wskazane jest, aby rodzic przyjeżdżał raz w miesiącu na spotkania dla rodzin. Często zaniepokojeni dzwonią do ośrodka w Pałęgach i pytają jak się czuję ich dziecko i czy jest postęp w procesie terapeutycznym. Je-

${ }^{1}$ Imiona pacjentów i ich rodziców zostały zmienione ze względu na ochronę danych osobowych śli pacjent przestrzega zasad, to rodzina chwilowo odczuwa spokój i zadowolenie, którego od dawna nie zaznała. Warto wskazać, iż zachowanie pacjenta uzależnionego $\mathrm{w}$ początkowych etapach leczenia jest niestabilne i ulega zmianie z dnia na dzień, dlatego rodzice często odczuwają niepewność, niepokój, strach.

\section{Realizacja kontraktu terapeutycznego przez ro- dzinę}

Bardzo istotnym aspektem jest to, aby rodzice - zwłaszcza pacjentów niepełnoletnich przyjęli do wiadomości, że dla właściwego procesu leczenia wskazany jest stały kontakt $\mathrm{z}$ poradnia leczenia uzależnień w miejscu zamieszkania. Jest to szczególnie ważne, gdyż poprzez uczestnictwo opiekunów w zajęciach grupowych ośrodka jak również podjęcie terapii można uzyskać wzmocnienie działań terapeutycznych. 0 tych wymaganiach stanowi kontrakt, który rodzice podpisują i zobowiązują się do jego przestrzegania $\mathrm{w}$ dniu przyjęcia dziecka do ośrodka. Realizacja tych ustaleń wygląda różnorodnie w zależności od rodziny i jej priorytetów. Zdarzają się opiekunowie, którzy bez zastrzeżeń wypełniają dane wymogi i są otwarci na współpracę z zespołem specjalistów. Jednak bywają tez tacy, którzy sporadycznie odwiedzają swoje dziecko i nie uczestniczą w terapii. Jest to niezwykle ważne gdyż leczenie uzależnienia jest długotrwałym procesem poruszającym szereg różnorodnych problemów i trudności dziecka w relacjach rodzinnych. Efekty odpowiedniej współpracy terapeutycznej są widoczne wtedy, gdy rodzic uczęszcza na terapię i systematycznie przyjeżdża na spotkania rodzin. Spotkałam się niejednokrotnie z oporem bliskich przed podjęciem terapii, który rzutuje na współpracę i na progres w leczeniu. Jednak ci rodzice, którzy zdecydowali się na leczenie mówią o korzyściach z podjętej decyzji i zachęcają innych, aby zdecydowali się na ten krok.

\section{Przypadek drugi: Igor, lat czternaście - uzależ- niony od marihuany i amfetaminy.}

Od trzynastego roku życia zaczął palić marihuanę i dwa razy $w$ tygodniu przyjmował doustnie amfetaminę. Przyjechał do ośrodka pod naciskiem rodziców i na początku nie wykazywał zainteresowania leczeniem. Twierdził, że nie jest uzależniony i zgodził się na leczenie pod naciskiem mamy. Jego zaangażowanie $\mathrm{w}$ terapię było minimalne. W momencie kiedy pacjent otrzymał zadanie terapeutyczne polegające na zaangażowaniu się w funkcję szefa kuchni nastąpiła zmiana $\mathrm{w}$ podejściu do leczenia. Z rozmów terapeutycznych wynikało, iż pacjent poprzez tę odpowiedzialność nauczył się otwartości, umiejętności planowania, organizacji czasu wolnego. Zadanie to wymagało kontaktu z ludźmi, co spowodowało iż pacjent zaczął mówić o swoich uczuciach, a to z kolei przyczyniło się do 
zwiększenia zaufania. Określał swoje problemy i cele w Indywidualnym Planie Terapeutycznym, aż do tego stopnia, iż zaczął on myśleć o skończeniu całego programu terapii. Aktywność pacjenta w trakcie leczenia wzrosła. Elementem stymulującym ten proces okazało się otrzymanie przez Igora odpowiedzialnej funkcji. Potwierdzeniem mechanizmu zmiany podejścia do leczenia są słowa W. R. Millera: „zarówno badania, jak i doświadczenie sugerują, że motywacja jest stanem dynamicznym, który może się zmienić wraz z upływem czasu i w relacji do różnych sytuacji, nie jest to statyczny atrybut, raz na zawsze człowiekowi przypisany. Motywacja może zostać zachwiana w styczności z przeciwstawnymi celami. Zmienia się również intensywność motywacji; słabnie w reakcji na wątpliwości i rośnie, kiedy wątpliwości są wyjaśniane, a cele stawiane klarowniej. W tym znaczeniu może być ambiwalentna, to znaczy być stanem unikania jasnej odpowiedzi lub zdecydowanej gotowości do działania lub jej braku" (Miller, 2009, s. 30).

W trakcie pobytu w ośrodku leczenia uzależnień w Pałęgach obserwowano u Igora wzrost zaangażowania. Plany jego uległy weryfikacji gdy dowiedział się od matki, że będzie przebywał w ośrodku krócej i nie ukończy całej terapii. Był to wówczas trudny czas dla Igora i jego motywacja znacznie się osłabiła, co przejawiało się w tym, że pacjent nie realizował kontraktu terapeutycznego. Nie podejmował określonych zadań, a jego wysiłek wkładany w obowiązki był minimalny. Spowodowało to, że pacjent zaczął zaniedbywać obowiązki szkolne, aż do tego stopnia, że groziła mu ocena niedostateczna z języka angielskiego. Ostatecznie zakończyło się to rezygnacją z terapii pomimo tego, że pacjent rozważał kontynuowanie leczenia.

Warto zaznaczyć, że niektórym rodzicom nie zależy, aby ich dziecko ukończyło pełny program terapeutyczny. Dodam, iż rodzina Igora nie podjęła terapii pomimo zaleceń, co w znacznym stopniu mogło przyczynić się do podjęcia decyzji o przerwaniu leczenia. $W$ tym konkretnym przypadku brak wiedzy na temat narkomanii i tęsknota za synem mogły przyczynić się do przerwania terapii. Pomimo tego, że dziecko dążyło do zmiany to działanie rodziny przyczyniło się do osłabienia chęci leczenia. Opiekunowie zapominają, że narkomania jest chorobą nieuleczalną i śmiertelną. Myślą, że odbierają $\mathrm{z}$ ośrodka zdrowe dziecko, a tymczasem choroba może postępować i dalsza kontynuacja leczenia jest niezbędna.

\section{Przypadek trzeci: Marek, lat piętnaście - uzależ- niony od alkoholu i dopalaczy.}

Od roku upijał się alkoholem i dwa razy w tygodniu przyjmował dopalacze. Wobec niego toczyła się sprawa w Sądzie o groźby karalne. U chłopca występowało również uzależnienie od komputera. Z biegiem lat czas spędzany na tej formie rozrywki ulegał zwiększeniu. W wieku siedmiu lat spędzał około sześć godzin grając w gry komputerowe, a gdy miał jedenaście lat zdarzało się, że poświęcał na to cały dzień. Zaniedbywał naukę szkolna, a w relacjach rodzinnych często występowały kłótnie i zachowania agresywne. Bezsilność rodziców spowodowała, iż szukali oni pomocy w Poradni Uzależnień. Marek na spotkania terapeutyczne uczęszczał tylko pod naciskiem rodziców. Po kilku wizytach specjalista skierował ich syna do długoterminowego ośrodka leczenia uzależnień w Pałęgach. Początkowo pacjent wykazywał opór wobec zadań terapeutycznych, ale już po miesiącu ujawniał swoją potrzebę znaczenia i bycia ważnym wśród innych pacjentów społeczności terapeutycznej ośrodka. W związku z tym motywacja i zaangażowanie pacjenta znacznie wzrosło. Rodzicom początkowo bardzo zależało, aby syn pozostał i leczył się. Przyjeżdżali na każde spotkanie rodzin, ale z upływem czasu matka pacjenta zaczynała mieć wątpliwości. Ujawniała trudność w rozstaniu się z synem i podkreślała, że nie wyobraża sobie wakacji bez syna, gdyż co roku wyjeżdżali wspólnie $\mathrm{z}$ całą rodziną. Ponadto zafascynowana zmianą syna, jego sposobem mówienia i przeżywania uczuć oznajmiła terapeucie uzależnień, że pod koniec września myśli o zabraniu Marka z ośrodka. Po konsultacji ze specjalistą postanowiła jednak, że wyjadą bez dziecka. W tym przypadku tęsknota za synem oraz polepszenie kontaktu z dzieckiem spowodowały, że matka zastanawiała się czy warto kontynuować leczenie. Pani Krystyna ujawniała trudności pomimo systematycznej pracy terapeutycznej w Poradni Uzależnień lecz zdołała pokonać dylematy, rozterki związane $\mathrm{z}$ tęsknotą za synem. Pani Krystyna wspierała syna w terapii i towarzyszyła mu w jego kryzysach i postępach. Otwartość matki i odpowiednia współpraca z terapeutą przyniosły korzyści terapeutyczne. Opiekunowie szybko zapominają o stratach i szkodach wywołanych używaniem substancji psychoaktywnych. Terapia jest procesem i bardzo często zdarza się, że zaangażowanie pacjenta ulega zmianie.

\section{Granice w relacji rodzic - dziecko}

Temat granic to ważne zagadnienie, które dostrzegłam pracując $\mathrm{z}$ dziećmi i ich rodzinami. Utrzymanie prawidłowych granic przyczynia się do uzyskania pożądanych efektów terapeutycznych u osób niepełnoletnich. Jak zauważa A. Margasiński: „każdy system posiada swoje granice wyróżniające go $\mathrm{z}$ otoczenia, podobnie jest w przypadku rodziny. Granice zbyt mocne powodują utrudniony przepływ informacji pomiędzy rodziną a środowiskiem, na ogół charakterystyczne są dla rodzin sztywnych, bardzo zhierarchizowanych, często ksenofobicznych, o tendencjach lękowych. Z kolei granice nadmiernie przepuszczalne zagrażają rozmyciu tożsamości rodziny, występują w rodzinach słabo zhierarchizowanych, o luźnej strukturze, na ogół słabym poczuciu wzajemnej więzi. Za najbardziej optymalne uważa się granice elastyczne, zapewnia- 
my członkom rodziny poczucie rodzinnej wspólnoty i jedności, tożsamości, a jednocześnie umożliwiające adekwatne przystosowanie się do nowych sytuacji, zadań i stresów wynikających $\mathrm{z}$ relacji z otoczeniem" (Margasiński, 2010, s. 34-35).

\section{Przypadek czwarty: Sandra, lat siedemnaście - uzależniona od marihuany, amfetaminy.}

Nawiązując do kwestii granic przywołać warto przypadek - Sandry, która przebywała w ośrodku sześć miesięcy. Wcześniej używała co najmniej 2 razy w tygodniu substancji psychoaktywnych takich jak: marihuana, amfetamina. Jej rodzice rozwiedli się, gdy miała jedenaście lat, a główną przyczyną rozwodu był alkoholizm oraz stosowanie przemocy przez ojca. Miała trzech braci i jedną siostrę. Sandra w trakcie trwania terapii uzależnień wspominała, że bardzo często zdarzało się, że matka chodziła na spotkania z partnerami, a jej zostawiała rodzeństwo pod opieką i niejednokrotnie to było przyczyną kłótni z matką. Pacjentka nie mogła w ten sposób zaspokajać swoich potrzeb, a jej rola jako najstarszej córki polegała na opiece nad rodzeństwem. Podany przykład ukazuje, że rola dziecka sprowadzała się do opieki, co wpłynęło na brak zachowanych granic i odrębności jednostki. Potwierdzają to następujące słowa: „destrukcja relacji małżeńskiej skłania rodziców do szukania oparcia u dzieci. W wyniku tego zacierają się granice pomiędzy światem dorosłych i dzieci. Następuje zamiana ról- to dzieci zaspokajają potrzeby dzieci swoich rodziców: podejmują obowiązki opieki wobec młodszego rodzeństwa, stają się powiernikami rodziców, ich opiekunami" (Karasowska, Szulirz, 2015, s. 34). Dodatkowo potwierdza fakt, że matka podczas rozmów telefonicznych informowała ją o wszelakich problemach z dziećmi czy nowo poznanymi partnerami. Sandra będąc w terapii bardzo to przeżywała, gdyż emocjonalnie była związana z rodzeństwem i czuła się za nie odpowiedzialna. Na podstawie obserwacji zachowań matki stwierdziłam, iż nie była należycie zainteresowana uczuciami córki. Sandra oczekiwała wsparcia i pomocy od rodzica. Pani Renata wielokrotnie składała obietnice córce, że przyjedzie na spotkanie rodzin, a jak się później okazywało - dzień wcześniej odmawiała wizyty. Dziewczyna płakała, gdy widziała innych rodziców odwiedzających swoje dzieci, gdyż bardzo pragnęła się zobaczyć z matką i rodzeństwem. Kontakt $\mathrm{z}$ rodzicielką pacjentki był utrudniony, a współpraca była minimalna. Trudnością Sandry w pracy terapeutycznej było branie na siebie odpowiedzialności za innych ludzi. Troszczyła się głównie o innych zapominając o sobie i swoich potrzebach i szybko wchodziła w bliskie relacje damsko -męskie. Schemat jej zachowań odzwierciedla to, czego doświadczyła w rodzinie. Brak prawidłowych granic w rodzinie spowodował, iż pacjentka wykonywała zadania osób dorosłych.
W literaturze przedmiotu spotykamy się ze stwierdzeniem, że „rodzinne tematy pomagają organizować tożsamość rodziny; pomagają zrozumieć członkom systemu rodzinnego wzajemne oczekiwania i oddziaływania; wspomagają też kształtowanie własnych tożsamości przez spostrzeganie siebie $\mathrm{w}$ relacjach interpersonalnych $\mathrm{w}$ granicach i na zewnątrz rodziny" (Plopa, 2005, s. 21).

$\mathrm{Na}$ podstawie własnych doświadczeń w pracy terapeutycznej mogę stwierdzić, że rodzice dosyć często przerzucają odpowiedzialność na swoje dzieci, co uwidacznia sie $\mathrm{w}$ terapii. Ponadto rodzice chcąc wynagrodzić dziecku pobyt w placówce, kupują mu nowe markowe ubrania, przesyłają dodatkowe paczki i spełniaja każde życzenie dziecka. Takie postępowanie może wzmacniać postawę roszczeniową, brak szacunku do dorosłych i przekłada się na mniejsze zaangażowanie w leczenie. Zachowanie opiekunów może wynikać z lęku i obawy przed rezygnacją dziecka z terapii. Wobec takich działań osób bliskich terapeuta indywidualny przeprowadza rozmowę i zaznacza, co służy terapii, a co jej przeszkadza. Jednakże to opiekunowie ostatecznie decydują o tym, czy zastosują się do sugestii terapeuty czy też nie.

\section{Konsekwencja w terapii uzależnień}

Ważny aspekt pracy pomocowej stanowi konsekwencja rodziców wobec swoich dzieci. Z przeprowadzonych rozmów, wywiadów diagnostycznych $\mathrm{z}$ pacjentami ośrodka $\mathrm{w}$ Pałęgach i ich rodzinami wynika, iż opiekunowie ujawniali trudności w byciu konsekwentnymi. 0 tym jak jest ważna konsekwencja ukazuje poniższy przykład.

\section{Przypadek piąty: Wiktoria, lat szesnaście - uza- leźniona od amfetaminy i dopalaczy}

Konsekwentne działanie rodziców potwierdza historia szesnastoletniej Wiktorii, która przyjechała na terapię pod naciskiem rodziców. Zażywała od roku amfetaminę i dopalacze. Kilka razy próbowała mefedron, ecstasy. Kilkakrotnie po zażyciu substancji psychoaktywnych przebywała w szpitalu. Zaniedbywała obowiązki szkolne, a relacje rodzinne uległy pogorszeniu. Opiekunowie stwierdzili, że jedyną pomocą będzie terapia uzależnień w ośrodku w Pałęgach. Gdy przyjechali do ośrodka dziewczyna początkowo okazywała zdziwienie słysząc o zasadach pobytu. Trudno jej było przyjąć, że nie wolno palić papierosów, ale postanowiła podjąć leczenie. Wiktoria podkreślała, że rodzice wobec niej próbowali wyegzekwować nowe zasady, które lekceważyła gdyż nie zamierzała zrezygnować z zażywania narkotyków. Można stwierdzić, iż działanie rodziców było konsekwentne, gdyż szukali nowych rozwiązań w trosce o swoje dziecko. Jest to niezwykle ważny temat gdyż „prawdziwa pomoc uzależnionemu musi zacząć się od tego, żeby zaczął ponosić konsekwencje swoich zachowań i decyzji, 
bo to umożliwi mu zauważenie problemu i może go skłonić do zmiany postępowania, a tym samym do podjęcia leczenia" (Woronowicz, 2014, s. 43). Terapia uzależnień swe działania opiera na wytrwałości, systematyczności w dążeniu do określonego celu. Ważne jest również aby rodzice nie ulegali manipulacji nieletniego, gdy ten nie będzie chciał kontynuować terapii. Istota skutecznych oddziaływań terapeutycznych polega również na tym, aby rodzic był przekonany o tym, że terapia dla swojego dziecka jest niezbędna. Ważne jest, aby wzmacniać dziecko do kontynuowania terapii bo wtedy może doświadczyć wiele dobrego.

\section{Podsumowanie}

Prezentowany artykuł i wyniki analizy indywidualnych przypadków wskazują na niezwykle zróżnicowane postawy rodziny i rodziców wobec terapii uzależnionych od narkotyków dzieci. W tym miejscu warto podjąć próbę odpowiedzi na pytania problemowe.

Rodzina w zróżnicowany sposób motywuje nastolatków do podjęcia terapii. Konsekwentne motywowanie przez rodziców pozwala nie tylko na zwiększenie szans podjęcia terapii ale i utrzymanie się w niej. To, co może przeszkadzać rodzinie w utrzymaniu konsekwentnych postaw wobec terapii dziecka jest tęsknota za dzieckiem czy nadmierna opiekuńczość ze strony któregoś rodzica. Ponadto zbyt nikłe zainteresowanie potrzebami i sytuacją dziecka oraz zaabsorbowanie osobistymi sprawami może stanowić o zaniedbywaniu i słabym motywowaniu dziecka do terapii. Pobyt dziecka w Ośrodku, trwający wiele miesięcy sprawia, że rodzice w zróżnicowany sposób przezywają brak dziecka w domu. Towarzyszą im często uczucia lęku, obaw, tęsknoty. Jeśli dziecko nie angażuje się w terapię doświadczają bezradności i bezsilności. U niektórych rodziców obserwowałam ulgę („bo problem jest poza mną, mają go na swojej głowie terapeuci") i spadek zainteresowania dzieckiem. U tych rodziców, którzy nawiązywali dobrą współpracę z terapeutami, potrafili nam zawierzyć, dzielili się wprost swoimi obawami pojawiała się postawa współpracy ale i cierpliwości w oczekiwaniu na efekty. Natomiast nadmierna opiekuńcza koncentracja uwagi na dziecku, ograniczona lub wycofana współpraca z terapeutami czy brak zainteresowania dzieckiem (poza deklaratywnością) to postawy niezwykle destrukcyjnie wpływające na uczestnictwo dziecka w terapii.

Podsumowujac przedstawione rozważania można stwierdzić, iż rodzina w terapii niepełno- letnich pacjentów stanowi absolutnie nieodłączny element. Jest niezwykle ważnym ogniwem w procesie zmiany nie tylko dla swoich dzieci, ale również dla terapeutów uzależnień. Bez współpracy z opiekunami nie zapewni się skutecznej pomocy. Autor jako specjalista terapii uzależnień uważa, że kontakt z rodziną jest dla pacjentów niezwykle cenny. To właśnie z bliskimi chorzy dzielą się radością, smutkiem, opowiadają co przeżyli, co osiągnęli albo z czym sobie nie radzą. Prawni opiekunowie stanowią dla nich największe wsparcie obok terapeutów uzależnień, pacjentów czy innych pracowników ośrodka. Ponadto kontakt z najbliższymi w trakcie trwania terapii ulega zmianie na lepsze. Uzależnieni ujawniają potrzebę pracy terapeutycznej nad poprawą relacji w rodzinie poprzez próbę wyjaśnienia wszelkich nieporozumień i kłamstw jakie stosowali względem rodzicieli. Z pomocą najbliższych osób można wypracować wzmacnianie gotowości do pracy nad swoim nałogiem, motywację do podjęcia odpowiedzialności i zaangażowania. Każdego dnia młodzież może podjąć wysiłek zmierzający ku realizacji określonych zadań terapeutycznych. Uzyskuje się to poprzez wymagania i oczekiwania rodziny. Rodzina może oddziaływać również negatywnie na leczenie dziecka, co przyczynia się do osłabienia jakości terapii. Jak wspomniano wcześniej uwidacznia się to brakiem zainteresowania dzieckiem, jego uczuciami, potrzebami, a w dalszej konsekwencji wpływa negatywnie na jego leczenie. Rodzice wówczas przyjeżdżają sporadycznie na spotkanie terapeutyczne w ośrodku i nie zależy im na rozmowie $\mathrm{z}$ terapeutą uzależnień, co w znacznym stopniu wpływa na pogorszenie współpracy. Motywacja w trakcie leczenia osłabia pacjentów, gdy opiekunowie opowiadają głównie o swoich dorosłych problemach i nie dotrzymują dziecku danego wcześniej słowa. Trudno patrzy się na łzy dziecka, które odczuwa smutek i mówi: „mama tym razem nie przyjedzie, a obiecała mi” lub „nie mogę pojechać do domu na przepustkę bo kolejny termin mamie nie odpowiada". Niejednokrotnie decyzje zespołu terapeutycznego, zwłaszcza związane $\mathrm{z}$ rozwiązaniem kontraktu terapeutycznego podlegają krytyce ze strony rodziny. Odnoszę jednak wrażenie, że czasami umieszczenie dziecka w stacjonarnym ośrodku leczenia uzależnień stanowi dla bliskich pełne rozwiązanie problemu. Tymczasem terapia niepełnoletniego dopiero się zaczyna i wymaga zintegrowanych działań ze strony rodzicieli, dziecka i specjalisty terapii uzależnień.

\section{Literatura:}

1. Baranowicz, K. (2001). Studium indywidualnego przypadku w pracy pedagoga specjalnego. W: Z. Palak (red.), Pedagogika specjalna $w$ reformowanym ustroju edukacyjnym (s. 115-124). Lublin: Wydawnictwo UMCS.

2. De Leon, G. (2003). Społeczność terapeutyczna. Warszawa: Krajowe Biuro ds. Przeciwdziałania Narkomanii. 
3. Durka, G. (2007). Prawna ingerencja w wychowanie dziecka w rodzinie. W: T. Sołtysiak, M. Gołembowska, (red.), Zagrożenia i zaburzenia funkcjonowania polskich rodzin (s. 131-140). Włocławek: Wydawnictwo Wyższa Szkoła Humanistyczno- Ekonomiczna.

4. Karasowska, A., Szulirz A. (2015). Ocalić więzi. Praca socjoterapeutyczna z rodzinq zagrożonq. Warszawa: Wydawnictwo ETOH.

5. Koczurowska, J. (2010). Społeczność terapeutyczna w rehabilitacji uzależnień. W: P. Jabłoński, B. Bukowska, J. Czabała (red.), Uzależnienie od narkotyków. Podręcznik dla terapeutów (s. 183-198). Warszawa: Krajowe Biuro ds. Przeciwdziałania Narkomanii.

6. Kooyman, M. (2002). Społeczność terapeutyczna dla uzależnionych. Warszawa: Krajowe Biuro Przeciwdziałania Narkomanii.

7. Łobocki, M. (2006). Metody i techniki badań pedagogicznych. Kraków: Oficyna Wydawnicza Impuls.

8. Margasiński, A. (2010). Rodzina alkoholowa z uzależnionym w leczeniu. Kraków: Oficyna Wydawnicza „Impuls”.

9. Miller, W. R. (2009). Wzmacnianie motywacji do zmiany w terapii nadużywania substancji. Zalecenia do Optymalizacji Terapii. Warszawa: Wydawnictwo Edukacyjne PARPAMEDIA.

10. Palacz-Chrisidis, A. (2014). Praca socjalna z osobami uzależnionymi i ich rodzina. Warszawa: Wydawnictwo Centrum Rozwoju Zasobów Ludzkich.

11. Pilch, T., Bauman, T. (2001). Zasady badań pedagogicznych. Strategie ilościowe i jakościowe. Warszawa: Wydawnictwo Akademickie Żak.

12. Plopa, M. (2005). Psychologia rodziny. Teoria i badania. Elbląg: Wydawnictwo Elbląskiej Uczelni Humanistyczno-Ekonomicznej.

13. Pstrąg, D. (2000). Wybrane zagadnienia z problematyki uzależnień. Rzeszów: Wydawnictwo Wyższej Szkoły Pedagogicznej.

14. Rajwa, E., Marynowicz S. (red.). (2002). Współczesna rodzina, funkcjonowanie zagrożenia terapia. Kraków: Wydawnictwo Małopolskie Centrum Doskonalenia Nauczycieli.

15. Rogala-Obłękowska, J. (2002). Narkomania w rodzinie: wskazania do terapii. Warszawa: Wydawnictwo Uniwersytetu Warszawskiego.

16. Woronowicz, B. (2014). Dasz radę. O pokonywaniu uzależnień. Warszawa: Wydawca Prószyński Media. 